\title{
EVALUASI PROGRAM PENYELENGGARAAN PENDIDIKAN DINIYAH TAKMILIYAH KOTA BANJAR
}

\section{Supriyanto}

Komite Tetap Peningkatan SDM, Diklat dan Litbang di Kadin Indonesia

\section{Burhanuddin Tola Universitas Negeri Jakarta}

\begin{abstract}
The research is aimed to find context, input, process, and product of program evaluation of Diniyah Takmiliyah Education in Banjar City. Method used in this research is case study. Evaluation research model applied in this research is CIPP model developed by stuffebeam at all. CIPP evaluation model consist of four components, including: context, input, process and product. Interview, questionnaires, observations and documents were used to collect the main data of the research. The data were analyzed using descriptive qualitative method. The research found that: I) All aspects of context component in Diniyah Takmiliyah education have fulfilled the assigned criteria. 2) Input component has not fulfilled the assigned criteria. There was an aspect remained unfulfilled including academic calender that belong to academic administration and facilities requirements. 3) Process component was catagorized in high level since all aspects have fulfilled the assigned criteria. 4) Product component has not fulfilled the assigned criteria. There were found any deficiency in the aspect of reciting the Holy al-Qur'an based on tajweed rules, writing the Arabic al-Qur'an, and memorizing certain hadist.
\end{abstract}

Keywords: Program Evaluation, CIPP Evaluation Model, Diniyah Takmiliyah Education

\begin{abstract}
ABSTRAK
Penelitian ini bertujuan untuk mengetahui konteks, masukan, proses, dan produk dari program penyelenggaraan pendidikan Diniyah Takmiliyah di Kota Banjar. Metode yang digunakan adalah studi kasus, model penelitian evaluasi yang digunakan adalah model CIPP dikembangkan oleh Stufflebeam dan kawan-kawan. Model evaluasi CIPP terdiri dari empat komponen, yaitu: konteks, input, proses dan produk. Teknik pengumpulkan data dilakukan dengan wawancara, angket, observasi, dan dokumentasi. Teknik analisis data yang digunakan adalah deskriptif kualitatif. Hasil penelitian menunjukkan hal-hal sebagai berikut: I) Komponen konteks program penyelenggaraan pendidikan Diniyah Takmiliyah semua aspek telah memenuhi kriteria yang ditetapkan. 2) Komponen masukan belum memenuhi kriteria karena beberapa aspek terdapat kekurangan yaitu aspek kalender akademik, persyaratan administrasi pendidik dan sarana prasarana 3) Komponen proses berada dalam kategori tinggi karena semua aspek telah memenuhi kriteria yang ditentukan. 4) Komponen produk belum sesuai dengan kriteria karena terdapat kekurangan pada aspek membaca al-Qur'an dengan kaidah tajwid, menulis al-Qur'an sesuai kaidah dan menghafal hadits pilihan.
\end{abstract}

Kata kunci: Evaluasi Program, Model Evaluasi CIPP, Pendidikan Diniyah Takmiliyah

\section{Pendahuluan}

Diniyah takmiliyah merupakan institusi pendidikan keagamaan Islam yang dilaksanakan dengan terpola serta bertingkat untuk suplemen tambahan serta pelengkap penyelenggaraan pelajaran agama Islam dalam tingkat pendidikan dasar dan menengah. Madrasah Diniyah atau pada saat ini kebanyakan dinamakan Madrasah Diniyah Takmiliyah (MDT) merupakan institusi pendidikan Islam yang diketahui semenjak lama beriringan dengan masa penyebaran Islam di Indonesia. Bimbingan pembelajaran dan pengajaran Islam lahir secara natural melalui jalan pencampuran dua kebudayaan yang saling bertemu dan mempengaruhi yang bergerak secara lembut namun pasti berdasarkan kepentingan populasi yang ada. Pada waktu kolonialisme yang nyaris seluruh kampung memiliki masyarakat yang beragama Islam, ada madrasah diniyah (Diniyah Takmiliyah), dengan sebutan dan formasi yang berlainan antara satu tempat dengan tempat 
lainnya, seperti, surau, pengajian, langgar, mushala, sekolah agama dan lain lain. Mata pelajaran agama juga berbeda beda yang yang pada umumnya meliputi membaca dan menulis al-Qur'an, akidah, akhlak, ibadah serta bahasa Arab.

Keberadaan Madrasah Diniyah Takmiliyah ini secara umum masih memiliki anggapan kurang memperoleh kepedulian tersendiri dari masyarakat umum serta pemerintah, padahal jika memandang kondisi kejiwaan, rohani batiniah, serta perilaku generasi sekarang ini sangat mengkhawatirkan. Bersamaan dengan perbedaan masa, pendidikan Diniyah Takmiliyah di banyak daerah saat ini bernasib kurang beruntung, sebuah ujaran "wujuduhu ka'adamihi" (walaupun kenyataanya ada namun keberadaannya seolaholah dirasakan tidak ada), tiada kemajuan yang signifikan sebagaimana masa lalu dari lembaga ini yang tetap berupaya bangkit untuk generasi penerus masyarakat kampung untuk menjadi religius.

Terdapat permasalahan di dalam pelaksanaan pendidikan diniyah takmiliyah, kondisi yang dikhawatirkan bisa menurun dari beberapa segi, sehingga gerak dan langkah Madrasah Diniyah Takmiliyah yang menjadi harapan masyarakat. Di beberapa daerah apalagi daerah perkotaan jumlah peserta didik pendidikan Diniyah Takmiliyah menurun sebagai akibat kebijakan yang tidak mendukung sehingga menjadi sedikit batu sandungan pengelola madrasah apabila tidak ada peraturan daerah yang mengatur kewajiban pendidikan diniyah takmiliyah ini. Banyak diantara orang tua/wali peserta didik yang merasa resah karena menganggap pendidikan agama di sekolah negeri yang kurang memuaskan dan dirasa kurang mencukupi untuk mendampingi putra-putrinya melaksanakan petunjuk ajaran agama.

Peran penting pendidikan Diniyah Takmiliyah menjadi sentral di tengah pendidikan yang cenderung sekuler sekarang. $\mathrm{Hal}$ tersebut menjadi pemicu keterlibatan para pendidik yang berkualitas dan profesional dalam pendidikan Diniyah Takmiliyah. Sementara ini ada sebuah anggapan bahwa urusan Diniyah Takmiliyah atau urusan pendidikan agama dan keagamaan itu menjadi dikotomi Kementerian Agama, padahal perlu diperjelas bahwa urusan pendidikan adalah urusan bersama sehingga perlunya maju bersamasama. Pengelolaan pendidikan Diniyah Takmiliyah perlu dilakukan secara profesional oleh semua pihak untuk melahirkan insan-insan yang cerdas secara pribadi dan sosial. Pendidikan Diniyah Takmiliyah menjadi sebuah prinsip dan landasan untuk menunjang serta mendukung kemajuan pembangunan di sebuah kabupaten/kota karena membangun Sumber Daya Manusia yang dilandasi iman taqwa sehingga berikutnya diharapkan dapat membangun fisik dan materi.

Pendidikan Diniyah Takmiliyah dapat mengambil fungsi lebih di dalam membantu peserta didik mengisi waktu luangnya di luar jam sekolah formal dengan kegiatan yang positif. Madrasah Diniyah Takmiliyah dapat pula memerankan fungsi talent scouting (pemandu bakat) dan menyediakan wahana aktualisasi diri bagi setiap peserta didik yang dapat menjadi tolak ukur keberhasilan proses pembelajaran dan pendidikan dalam arti yang sebenarnya. Untuk dapat mengakomodir itu, program penyelenggaraan lembaga ini menjadi sebuah wadah yang dinilai tepat. Pendidikan Diniyah Takmiliyah diberikan keleluasaan dari segi kurikulum dalam melaksanakan program pembelajarannya, dalam hal ini dapat menyelenggarakan muatan lokal yang relevan sehingga menjadi semakin dinamis sebagai upaya menyalurkan potensi peserta didik ke arah yang positif.

\section{Penyelenggaraan pendidikan Diniyah} Takmiliyah di Kota Banjar selama ini lebih diarahkan kepada kegiatan pembelajaran yang berbasiskan agama Islam dan beberapa muatan lokal pada kegiatan yang menjurus ke arah seni Islam. Maksud dari pelaksanaan pendidikan Diniyah Takmiliyah ini untuk menyempurnakan pengajaran pada setiap jenjang pendidikan. Penyelenggaraan program pendidikan $\mathrm{di}$ atas memiliki arah menyampaikan kecakapan beragama terhadap peserta didik untuk menumbuhkan kehidupannya selaku Warga Negara Indonesia yang berkepribadian islami. Pendidikan Diniyah Takmiliyah dinilai sangat membantu mempersiapkan peserta didik dalam mengetahui, menguasai, menjiwai, meyakini pengamalan tuntunan agama Islam dari akar asal utama yakni al-Qur'an serta hadits dengan menjalani kegiatan edukasi, petunjuk, arahan, latihan, serta pengalaman empirik. 


\section{Metode Penelitian}

Pendekatan penelitian yang digunakan dalam penelitian ini yaitu deskriptif kualitatif. Penelitian deskriptif kualitatif merupakan penelitian yang termasuk dalam jenis penelitian kualitatif. Tujuan dari penelitian ini adalah mengungkap fakta, keadaan, fenomena, variabel dan keadaan yang teriadi saat penelitian berialan dan menyuguhkan apa adanya. Penelitian deskriptif kualitatif menafsirkan dan menuturkan data yang bersangkutan dengan situasi yang sedang terjadi, sikap serta pandangan yang teriadi di dalam masyarakat, pertentangan dua keadaan atau lebih, hubungan antarvariabel, perbedaan antar fakta, pengaruh terhadap suatu kondisi dan lain-lain. Kegiatan penelitian ini meliputi pengumpulan data, menganalisis data, menginterprestasi data, dan diakhiri dengan sebuah kesimpulan berupa hasil rekomendasi yang mengacu pada penganalisisan data.

Sedangkan metode penelitian yang digunakan yaitu studi kasus (case studies). Studi kasus bertujuan untuk membuat penafsiran akurat mengenai karakteristik-karakteristik obyek yang diteliti. Tipe penelitian ini adalah berusaha memahami suatu unit sosial tertentu secara utuh dalam totalitas lingkungan tersebut. Studi kasus dalam beberapa referensi merupakan bagian dari penelitian kualitatif.

Evaluasi program merupakan salah satu jenis obyek dari penelitian evaluasi. Orientasi mendasar pada semua penelitian evaluasi adalah 'manfaat'. Manfaat yang dimaksud adalah menyediakan informasi untuk mengambil keputusan dalam kerangka untuk meningkatkan (to improve) layanan program penyelenggaraan pendidikan diniyah takmiliyah di kota Banjar khususnya dan kabupaten/ kota lain penyelenggara pendidikan diniyah takmiliyah.

Model riset evaluasi yang dipakai yaitu model CIPP yang dikembangkan Stuffebeam dan kawankawan. Evaluasi model CIPP terdiri dari empat komponen, yaitu: context, input, process, and product. Keunggulan model ini adalah memberikan suatu kajian yang komprehensif dari suatu fenomena sosial yang sedang diamati. Model CIPP berorientasi pada pengambilan keputusan (decision oriented).
Teknik pengumpulkan data dilakukan dengan wawancara, angket, observasi, dan studi dokumen. Teknik analisis data yang digunakan adalah deskriptif kualitatif.

\section{Hasil Penelitian dan Pembahasan}

Berdasarkan hasil penelitian dan pembahasan yang diuraikan, maka dapat diambil beberapa kesimpulan penelitian penyelenggaraan pendidikan Diniyah Takmiliyah Kota Banjar sebagai berikut:

I. Komponen Konteks

a) Aspek landasan hukum didapati dari hasil studi dokumentasi dan wawancara di lapangan bahwa legalitas formal atau dasar hukum regulasi terkait penyelenggaraan pendidikan Diniyah Takmiliyah di Kota Banjar sudah ada yaitu: I) Peraturan Pemerintah Nomor 55 Tahun 2007 tentang pendidikan Agama dan Keagamaan. Fungsi dari peraturan pemerintah sebagai pengaturan lebih lanjut dan amanat ketentuan dalam Undang-Undang Nomor 20 Tahun 2003 tentang Sistem Pendidikan Nasional. 2) Peraturan Menteri Agama Republik Indonesia Nomor I3 Tahun 2014 tentang Pendidikan Keagamaan Islam sebagai penjabaran lebih rinci dari hierarki dasar hukum di atasnya yaitu Peraturan Pemerintah Republik Indonesia Nomor 55 Tahun 2007 tentang Pendidikan Agama dan Pendidikan Keagamaan. Peraturan Menteri Agama ini menjadi salah satu landasan hukum penyelenggaraan pendidikan Madrasah Diniyah Takmiliyah karena pendidikan Diniyah Takmiliyah secara struktur formal kewenangan, hak dan kewajiban merupakan domain dari Kementerian Agama dan Pemerintah Daerah Kota Banjar sebagai fasilitator. Peraturan Menteri Agama Nomor I3 Tahun 2014 memberikan standar yang lebih baik mengenai berbagai aspek pendidikan diniyah dan memberikan kesempatan bagi masyarakat untuk berpartisipasi aktif dalam pendidikan keagamaan. 3) Peraturan Daerah Nomor 18 Tahun 2013 tentang Penyelenggaraan Pendidikan Al-Qur'an dan Diniyah Takmiliyah. Peraturan daerah tentang Diniyah Takmiliyah ini menjadi terobosan dalam menghadapi kendala-kendala yang terjadi di lapangan dalam menyelenggarakan program 
pendidikan Diniyah Takmiliyah. Kebijakan tentang penyelenggaraan Diniyah Takmiliyah ini mengatur maksud dan tujuan penyelenggaraan pendidikan al-Qur'an dan Diniyah Takmiliyah, jenjang pendidikan Diniyah Takmiliyah, masa pendidikan, pendidikan al-Qur'an, penyelenggara Madrasah Diniyah Takmiliyah, perizinan dalam penyelenggaraan Diniyah Takmiliyah, kurikulum, peserta didik, pendidik dan tenaga kependidikan, pengelolaan dan pengawasan, pembiayaan serta evaluasi dan sertifikasi/ijazah Madrasah Diniyah Takmiliyah. 4) Instruksi Kepala Daerah Kota Banjar Nomor 422/Ins.I32-Huk/05/2005 tentang Persyaratan Memasuki Sekolah Lanjutan Tingkat Pertama (SLTP) dan Sekolah Menengah Tingkat Atas (SLTA) di Kota Banjar yang merupakan embrio awal landasan hukum penyelenggaraan Diniyah Takmiliyah di Kota Banjar. Instruksi ini menjadi pemicu lahirnya Peraturan Daerah Kota Banjar karena diterbitkan sebelum Perda Nomor 18 Tahun 2013 dan erat hubungannya dengan penyelenggaraan Diniyah Takmiliyah di Kota Banjar. Instruksi kepala daerah ini jika diterjemahkan secara tersirat sebenarnya serupa dengan peraturan Wali Kota Banjar tentang pedoman penerimaan peserta didik baru TK/RA, SD/MI, SMP/MTs, SMA/SMK/MA negeri dan swasta di lingkungan Dinas Pendidikan dan Kebudayaan serta Kementerian Agama Kota Banjar yang diterbitkan setiap tahun pelajaran yaitu adanya klausul sertifikat Diniyah Takmiliyah menjadi salah satu persyaratan wajib dalam penerimaan peserta didik baru.

b) Aspek kebutuhan masyarakat, terlihat dengan jelas bahwa penyelenggaraan program pendidikan Diniyah Takmiliyah di Kota Banjar telah memenuhi kriteria yang telah ditetapkan sebab berdasarkan hasil wawancara dengan orang tua peserta didik, pendidik dan pemangku kebijakan menyatakan bahwa masyarakat Kota Banjar pada umumnya serta peserta didik usia sekolah pada khususnya sangat membutuhkan penyelenggaraan pendidikan keagamaan non formal ini. Hal tersebut juga didukung dari hasil angket yang diiisi oleh peserta didik Madrasah Diniyah
Takmiliyah bahwa aspek kebutuhan masyarakat mendapatkan persentase sebesar 92,14\% masuk dalam kategori tinggi, artinya mereka masih menganggap bahwa keberadaan Madrasah Diniyah Takmiliyah dibutuhkan di tengah-tengah lingkungannya. Penyelenggaraan pendidikan keagamaan ini justru muncul dari masyarakat Kota Banjar sendiri sejak lama. Program pendidikan Diniyah Takmiliyah secara masif dilaksanakan oleh masyarakat sehingga dapat menjaring hampir semua peserta didik usia TK sampai dengan SLTP. Terdapat kekuatan kultural dan kemandirian masyarakat yang demikian besar dalam penyelenggaraan pendidikan keagamaan di lingkungannya.

II. Komponen Input

a) Aspek kurikulum telah memenuhi kriteria yang ditetapkan berdasarkan hasil observasi dalam aspek kurikulum didapatkan dari hasil wawancaran, studi dokumen serta hasil observasi diperoleh persentase sebesar 85\% masuk dalam kategori tinggi karena kurikulum Madrasah Diniyah Takmiliyah telah disusun sesuai dengan jenjang pendidikan yaitu, kurikulum Madrasah Diniyah Takmiliyah Awaliyah (MDTA) yang ditempuh dalam 4 (empat) tahun masa belajar, dari kelas I hingga kelas IV. Kemudian kurikulum Madrasah Diniyah Takmiliyah Wustha (MDTW) yang ditempuh dalam 2 (dua) tahun masa belajar, dari kelas I hingga kelas II dan selanjutnya kurikulum Madrasah Diniyah Takmiliyah Ulya (MDTU) yang ditempuh dalam 2 (dua) tahun masa belajar, dari kelas I hingga kelas II. Madrasah Diniyah Takmiliyah telah memiliki struktur kurikulum yang merupakan kerangka umum program pengajaran yang diberikan pada tiap jenjang pendidikan Madrasah Diniyah Takmiliyah di atas. Dalam struktur kurikulum meliputi tujuh satuan mata pelajaran (alQur'an, hadits, akidah, akhlak, fikih ibadah, sejarah kebudayaan Islam/tarikh dan Bahasa Arab) serta muatan lokal yang diberikan pada Madrasah Diniyah Takmiliyah berikut frekuensi dan alokasi waktunya dalam satu minggu. Dari sisi landasan kurikulum, pada Madrasah Diniyah Takmiliyah juga telah diterbitkan peraturan yang menjadi pedoman pengembangan kurikulum madrasah yaitu 
Keputusan Direktur Jenderal Pendidikan Islam Nomor 2349 Tahun 2012 tentang Pedoman Pengembangan Kurikulum Madrasah Diniyah Takmiliyah dilanjutkan kemudian dengan dikeluarkannya Keputusan Direktur Jenderal Pendidikan Islam Nomor 2350 Tahun 2012 tentang Pedoman Standar Nasional Pendidikan Madrasah Diniyah Takmiliyah dalam Standar Isi dan Standar Kelulusan yang menjadi jawaban atas kebutuhan kurikulum madrasah. Standar Kompetensi Lulusan dan standar isi mata pelajaran telah disusun untuk mencapai tahap demi tahap tujuan penyelenggaraan Madrasah Diniyah Takmiliyah. Dengan diterbitkan dan diterapkannya peraturan tersebut, maka pengembangan kurikulum Madrasah Diniyah Takmiliyah (MDT) telah memiliki standar secara prinsip.

b) Aspek kalender akademik, dalam kalender akademik/pendidikan ini belum memenuhi kriteria yang ideal sebab berdasarkan hasil wawancara, studi dokumen dan dari hasil observasi aspek kalender akademik diperoleh hasil $45 \%$ masuk dalam kategori rendah sebab berdasarkan temuan penelitian yang dilakukan, pihak yang berwenang dalam hal ini adalah Kementerian Agama Wilayah Provinsi Jawa Barat tidak lagi mengeluarkan petunjuk pelaksanaan kalender pendidikan secara rutin untuk pendidikan Diniyah Takmiliyah ini di setiap tahun pelajaran.

c) Aspek peserta didik, sebagaimana dari hasil temuan wawancara, data dokumentasi dan didukung hasil observasi di lapangan dari aspek peserta didik mendapatkan hasil persentase sebesar $81 \%$ masuk dalam kategori tinggi, artinya tingkat partisipasi peserta didik dalam pendidikan Diniyah Takmiliyah ini sangat tinggi. Tingkat serapan program penyelenggaraan Madrasah Diniyah Takmiliyah terhadap sasaran program yaitu peserta didik di Kota Banjar sangat besar. Hampir sebagian besar peserta didik usia sekolah di jenjang SD dan SLTP di Kota Banjar merupakan santri pada Madrasah Diniyah Takmiliyah.

d) Aspek persyaratan administrasi dan kompetensi pendidik, berdasarkan Keputusan Direktur Jenderal Pendidikan Islam Nomor 2348 Tahun 2012 tentang Pedoman Standar Nasional Pendidikan Diniyah Takmiliyah dalam
Pendidik dan Tenaga Kependidikan sebenarnya telah ditetapkan bahwa pendidik Madrasah Diniyah Takmiliyah adalah tamatan pendidikan Madrasah Diniyah Formal, Madrasah Diniyah non Formal, atau pendidikan yang sederajat yang dibuktikan dengan ijazah/surat keterangan/pengakuan legal formal dari lembaga instansi terkait. Berdasarkan hasil oservasi di lapangan dalam aspek syarat administrasi pendidik mendapatkan persentase hanya sebesar $25 \%$ dengan kategori rendah. Artinya, kualifikasi akademik secara administrasi/legal formal belum diterapkan secara mutlak dalam persyaratan rekrutmen peserta didik. Sebaliknya, dari hasil wawancara didapatkan bahwa persyaratan kompetensi pendidik terutama kompetensi keagamaan menjadi salah satu kriteria dalam perekrutan pendidik Madrasah Diniyah Takmiliyah. Hal ini didukung dari observasi di lapangan yang didapatkan hasil $83 \%$ masuk dalam kategori tinggi, artinya penyelenggara secara umum mencari para pendidik yang potensial di lingkungannya terutama dari sisi kemampuan membaca alQur'an sesuai kaidah serta pemahaman materi keagamaan untuk diterima menjadi pendidik di madrasahnya walaupun masih dalam tataran pengamatan subyektif penyelenggara madrasah.

e) Aspek sarana prasarana, masih dalam kategori sedang karena berdasarkan hasil wawancara didapatkan bahwa Madrasah Diniyah Takmiliyah di Kota Banjar belum memiliki sarana prasarana yang memadai dan layak sesuai standar. Hal ini didukung dengan observasi di lapangan yang mendapatkan hasil persentase sebesar 75,57\% dalam kategori sedang. Artinya, untuk kegiatan pembelajaran sarana prasarana belum cukup memadai karena pemenuhan kebutuhan sarana dan prasarana masih dilakukan secara swadaya oleh madrasah sendiri atau penyelanggara madrasah dalam hal ini adalah Dewan Kemakmuran Masjid.

\section{Komponen proses}

a) Aspek penguasaan materi pembelajaran oleh pendidik Madrasah Diniyah Takmiliyah dari 
hasil wawancara sudah memenuhi kriteria ideal, serta didukung dari angket aspek penguasan materi pembelajaran oleh pendidik yang mendapatkan hasil $80,80 \%$ berada dalam kategori tinggi, artinya para pendidik Madrasah Diniyah Takmiliyah secara umum menguasai materi, struktur, konsep dan pola pikir keilmuan yang mendukung mata pelajaran yang diampu yakni materi keagamaan sesuai kurikulum Madrasah Diniyah Takmiliyah. Faktor latar belakang pendidikan keagamaan para pendidik baik dari pondok pesantren, pendidikan keagamaan formal misalnya Mts/MA maupun pendidikan keagamaan non formal misalnya kursus/diklat keagamaan/bimbingan keagamaan dan pengalaman mendidik pada satuan pendidikan Diniyah Takmiliyah menjadi daya dukung para pendidik menguasai materi pembelajaran keagamaan madrasah.

b) Aspek minat pendidik berdasarkan wawancara dan dokumentasi telah memenuhi kriteria standar. Didukung oleh angket yang mendapatkan hasil $82 \%$ dengan kategori tinggi yang berarti pendidik Madrasah Diniyah Takmiliyah merupakan pendidik yang memiliki atensi, hasrat dan kecenderungan yang tinggi dalam mengabdi di Madrasah Diniyah Takmiliyah. Faktor keaktifan hadir dalam kegiatan belajar mengajar serta minimnya honor yang jauh dari layak dapat menjadi indikator sedemikian besar dedikasi dan loyalitas mereka untuk berpartisipasi dalam mencerdaskan kehidupan bangsa.

c) Aspek penguasaan metode pembelajaran oleh pendidik diperoleh kriteria standar dengan kategori tinggi. Berdasarkan hasil angket, penguasaan metode pembelajaran oleh pendidik mendapatkan persentase $82,34 \%$ dengan kategori tinggi. Didukung dengan pengumpulan data wawancara dan observasi di lapangan didapatkan temuan bahwa mereka menguasai teknik penyajian untuk menyampaikan materi pembelajaran kepada peserta didik di dalam kelas baik secara individual maupun secara kelompok sehingga materi pembelajaran pada Madrasah Diniyah Takmiliyah dapat diterima dan dimanfaatkan oleh peserta didik. Dalam memberikan materi pengajaran para pendidik di masing-masing Madrasah memiliki pola yang khas untuk diterapkan. Hal ini dapat dijelaskan bahwa para pendidik dalam mentransfer ilmu telah menggunakan cara kerja yang sistematis dalam pelaksanaan kegiatan pembelajaran di Madrasah Diniyah Takmiliyah. Mereka secara tidak langsung telah banyak mengadopsi cara yang biasa digunakan lembaga pesantren dalam proses belajar mengajar namun tetap disesuaikan dengan penyelenggaraan di Madrasah Diniyah Takmiliyah.

d) Aspek profil pendidik juga telah memenuhi kriteria yang dipersyaratkan yakni dalam kategori yang tinggi. Berdasarkan hasil angket didapatkan data dengan persentase $82,08 \%$ dengan kategori tinggi. Didukung dengan data wawancara dan dokumen didapatkan temuan bahwa figur dan potret seorang pendidik di Madrasah Diniyah Takmiliyah di Kota Banjar adalah orang yang memiliki keberdayaan mewujudkan kinerja sesuai dengan fungsi dan peranannya secara optimal. Perwujudan ini terlihat melalui keunggulan dalam pengetahuan keagamaan, sikap afeksi mereka sebagai seorang pendidik keagamaan, serta dari segi keterampilan profesional pendidik.

e) Aspek kehadiran peserta didik pada kategori tinggi, berdasarkan studi dokumen di lapangan mendapatkan hasil rata-rata persentase 77\% peserta didik hadir dalam kegiatan belajar mengajar sedangkan untuk jenjang wustha mengalami gangguan disebabkan kebijakan full day school di sekolah formal sehingga berpengaruh dalam kehadiran mereka di madrasah.

\section{Komponen produk}

a) Aspek membaca al-Qur'an masih dalam kategori sedang berdasarkan hasil observasi tes perbuatan (performance test) di lapangan dengan obyek peserta didik mendapatkan hasil persentase $70 \%$ masuk dalam kategori sedang. Apabila distandarkan dari kriteria kaidah tajwid. Membaca al-Qur'an dengan baik dan benar sesuai kaidah tajwid masih perlu penyempurnaan. Hal ini juga didukung oleh hasil wawancara yang mendapatkan temuan bahwa membaca al-Qur'an secara umum belum sempurna kaidah tajwidnya. 
Kemampuan membaca al-Qur'an peserta didik masih dalam hal kefasihan melafalkan makhraj huruf al-Qur'an serta kelancaran membaca secara tartil. Sedangkan untuk menulis dengan menggunakan huruf Arab, kecakapan menulis huruf Arab berdasarkan wawancara dan didukung dengan observasi langsung kepada peserta didik melalui tes perbuatan mendapatkan hasil $50 \%$ masuk dalam kategori rendah. Artinya kemampuan menulis huruf Arab di kalangan peserta didik baru sebatas keterampilan menyalin dari buku Iqra' atau mushaf al-Qur'an. Apabila diminta untuk imla' atau dikte tulisan Arab secara langsung oleh gurunya, peserta didik banyak yang belum mampu menuliskan dengan benar sesuai kaidah penulisan.

b) Aspek menghafal surat pendek dan ayat pilihan dalam al-Qur'an didapatkan hasil persentase menghafal surat pendek dalam Al-Qur'an adalah $83 \%$ dengan kategori tinggi, artinya peserta didik telah memenuhi kriteria dalam aspek menghafal surat pendek dalam alQur'an. Sedangkan dalam menghafal hadits pilihan berdasarkan hasil wawancara masih dalam kategori sedang serta berdasarkan hasil observasi yang didapatkan persentase sebesar 70\%. Kemampuan menghafal hadits dipengaruhi oleh penggunaan bahasa Arab yang dipergunakan dalam bahasa hadits, jumlah waktu pelajaran kurang, serta kedisiplinan mengulang hafalan. Dengan adanya metode pembelajaran menghafal hadits yang sudah baik dari pendidik seharusnya diimbangi oleh keaktifan peserta didik dalam muraja'ah (mengulang hafalan) secara mandiri.

c) Aspek praktek ibadah secara umum berada dalam kategori tinggi, artinya pengetahuan peserta didik dalam praktek ibadah sehari-hari dalam kategori baik, misalnya wudhu, salat, dzikir, doa, puasa dan lainnya. Hal ini didukung dengan data yang berdasarkan wawancara dan dokumentasi dengan beberapa pendidik, kepala madrasah serta orang tua peserta didik, kemampuan praktek ibadah peserta didik sangat terbantu dengan adanya Madrasah Diniyah Takmiliyah. Peserta didik mempelajari fikih ibadah mulai dari yang terkecil misalnya thaharah (bersuci), tata cara berwudhu, menguasai bacaan-bacaan shalat, mengenal tata cara pelaksanaan shalat 5 waktu, mengenal tata cara shalat jamaah, dzikir dan doa, puasa serta sedekah. Kemampuan ini terbantu oleh praktek ibadah yang dilaksanakan dalam kehidupan sehari-hari.

d) Aspek ilmu (wawasan) keislaman berdasarkan hasil wawancara mencapai kriteria tinggi. Sesuai kurikulum, terdapat tujuh mata pelajaran yang diajarkan di Madrasah Diniyah Takmiliyah yang meliputi al-Qur'an, hadits, akidah, akhlak, fikih ibadah, sejarah kebudayaan Islam, Bahasa Arab menjadi faktor yang sangat mendukung terjadinya penambahan dan pelengkapan materi pendidikan keisalaman bagi peserta didik ditambah lagi proses pembelajaran dilaksanakan 6 hari dalam sepekan. Peserta didik pada Madrasah Diniyah Takmiliyah mengalami peningkatan pengetahuan materi keagamaan Islam sebagaimana yang mereka dapatkan di Madrasah Diniyah Takmiliyah. $\mathrm{Hal}$ ini sebenarnya telah sesuai dengan tujuan diselenggarakannya program ini yaitu untuk menambah dan melengkapi Pendidikan Agama Islam di sekolah formal.

e) Aspek keterlibatan kegiatan kemasyarakatan dalam kriteria yang tinggi karena berdasarkan dokumentasi, observasi dan hasil wawancara, Madrasah Diniyah Takmiliyah seringkali dilibatkan dalam kegiatan kemasyarakatan di sekitar lingkungan madrasah, desa maupun tingkat kota. Warga madrasah seringkali dilibatkan dalam kegiatan kemasyarakatan terutama yang berhubungan dengan acara keagamaan di lingkungannya, misalnya kegiatan Peringatan Hari Besar Islam baik di tingkat lingkungan masjid, desa/kelurahan, kecamatan dan tingkat kota.

f) Aspek penghargaan juga mendapatkan kriteria yang tinggi sebab berdasarkan data dokumentasi dan wawancara setiap madrasah maupun peserta didik di dalamnya seringkali dilibatkan dalam perlombaan Madrasah Diniyah Takmiliyah yang tujuannya untuk mendapatkan penghargaan/medali/piala. Apalagi ada wadah khusus Madrasah Diniyah Takmiliyah dalam menyalurkan bakat, potensi dan kemampuan mereka dalam keagamaan, olahraga dan seni. Wadah yang rutin dan resmi perlombaan 
antara Madrasah Diniyah Takmiliyah ini dinamakan PORSADIN (Pekan Olahraga dan Seni Santri Diniyah).

\section{Kesimpulan}

Penelitian evaluasi menggunakan model CIPP yang Evaluasi model CIPP terdiri dari empat komponen, yaitu: context, input, process, and product. Keunggulan model ini adalah memberikan suatu kajian yang komprehensif dari penyelenggaraan pendidikan Diniyah Takmiliyah yang sedang diamati. Model CIPP berorientasi pada pengambilan keputusan (decision oriented).

Dari segi konsep, pendidikan Diniyah Takmiliyah dalam rangka untuk melengkapi/menyempurnakan pendidikan agama Islam yang diperoleh di sekolah formal dalam kerangka penumbuhkembangan iman dan takwa serta berorientasi pada kepribadian islami Hasil penelitian menunjukkan hal-hal sebagai berikut: I) Komponen konteks program penyelenggaraan pendidikan Diniyah Takmiliyah semua aspek telah memenuhi kriteria yang ditetapkan. 2) Komponen masukan belum memenuhi kriteria karena beberapa aspek terdapat kekurangan yaitu aspek kalender akademik, persyaratan administrasi pendidik dan sarana prasarana 3) Komponen proses berada dalam kategori tinggi karena semua aspek telah memenuhi kriteria yang ditentukan. 4) Komponen produk belum sesuai dengan kriteria karena terdapat kekurangan pada aspek membaca al-Qur'an dengan kaidah tajwid, menulis al-Qur'an sesuai kaidah dan menghafal hadits pilihan.

Dari hasil temuan-temuan yang didapatkan, maka rekomendasi yang diajukan sebagai berikut:

a. Kepala Daerah Kota Banjar

I) Penyelenggaraan pendidikan Diniyah

Takmiliyah di Kota Banjar perlu mendapatkan perhatian lebih maksimal berupa adanya landasan hukum yang lebih operasional. Dalam memberikan daya dukung yang lebih optimal dalam menuju keberhasilan penyelenggaraan pendidikan Diniyah Takmiliyah maka Peraturan Daerah perlu dikembangkan menjadi lebih operasional yaitu dengan diterbitkannya Peraturan Wali Kota (Perwal). Maksud dibentuknya Peraturan Wali Kota (Perwal) adalah untuk memberikan pedoman teknis dalam pengelolaan dan penyelenggaraan pendidikan Diniyah Takmiliyah di Kota Banjar.
Tujuan dibentuknya Peraturan Wali Kota (Perwal) adalah untuk memberikan arah teknis dalam penyelenggaraan pendidikan Diniyah Takmiliyah di Kota Banjar agar pelaksanaannya dapat dilakukan dengan baik, profesional dan akuntabel serta memberdayakan semua komponen masyarakat melalui peran serta dalam pengelolaan dan penyelenggaraan pendidikan Diniyah Takmiliyah di Kota Banjar.

2) Kenaikan bantuan honor pendidik madrasah dalam setiap bulannya sehingga sesuai kebutuhan hidup layak bagi pendidik madrasah. Bagaimanapun juga pendidik pada Madrasah Diniyah Takmiliyah adalah ujung tombak pendidikan yang tumbuh dari masyarakat yang peran dan dampaknya langsung dirasakan oleh masyarakat terutama dalam pembangunan Sumber Daya Manusia pada pendidikan keagamaan di daerah.

3) Pemenuhan dan penyempurnaan kelengkapan sarana prasarana yang memadai guna memberikan layanan pendidikan madrasah yang lebih baik. Dengan sarana prasarana yang memadai diharapkan mendukung jalannya proses pembelajaran yang lebih efektif dan bermakna bagi peserta didik dan pendidik. Pentingnya pemenuhan bantuan kelengkapan sarana pra sarana misalnya berupa meja kursi, alat peraga pembelajaran, perpustakaan serta sarana administrasi berupa komputer dan printer

b. Kementerian Agama Republik Indonesia

I) Aspek strategi dan desain program penyelenggaraan pendidikan Diniyah Takmiliyah yaitu pada kalender akademik. Petunjuk pelaksanaan kalender akademik Madrasah Diniyah Takmiliyah perlu diterbitkan kembali secara rutin setiap tahun pelajaran oleh Kementerian Agama sebagai pedoman resmi penyelenggaraan pembelajaran Madrasah Diniyah Takmiliyah.

2) Sosialisasi kebijakan secara stimultan yang berhubungan dengan kebijakan umum maupun khusus misalnya administrasi kurikulum (silabus, standar isi kurikulum, standar kompetensi lulusan, bahan ajar)

3) Rekomendasi dari aspek implementasi program adalah perlunya pembinaan pendidik melalui pendidikan latihan serta kegiatankegiatan profesional lainnya secara bersinergi 
dan berkelanjutan bagi semua pendidik yang mengajar pada Madrasah Diniyah Takmiliyah sehingga mereka lebih menguasai materi serta metode pembelajaran terkini dengan standar berkualitas yang pada akhirnya nanti semua pendidik dapat memiliki standar kompetensi yang diharapkan.

4) Pengawasan dan pengontrolan dari pihak regulator baik Kementerian Agama serta Pemerintah Kota sangat diperlukan karena dapat dikategorikan sebagai evaluasi terhadap keberadaan serta pelaksanaan pendidikan Diniyah Takmiliyah. Peran Kementerian Agama selaku regulator sehingga perlu melaksanakan pengawasan, pembinaan serta evaluasi yang lebih intensif supaya standarisasi keluaran atau output dari berbagai Madrasah Diniyah Takmiliyah memiliki kualitas yang standar dan merata. Dengan demikian dampak atau output program pendidikan Diniyah Takmiliyah ini dapat dirasakan oleh semua pihak.

c. Kepala Madrasah

I) Dari segi kurikulum perlu diberlakukan jumlah jam pembelajaran dalam setiap mata pelajaran selama satu minggu disesuaikan dengan struktur kurikulum berdasarkan pedoman pengembangan kurikulum Madrasah Diniyah Takmiliyah karena secara umum madrasah masih menggunakan pola satu jam dalam setiap pertemuan hanya diajarkan satu mata pelajaran.

2) Penerapan persyaratan administrasi pendidik dalam rekrutmen pendidik sehingga sesuai dengan standar kualifikasi akademik yang menjadi kebutuhan dalam penyelenggaraan program. Kualifikasi akademik ini menjadi salah satu bukti legal formal bagi penjaminan kualitas guru Madrasah Diniyah Takmiliyah.

3) Kehadiran peserta didik, perlunya ditata ulang kembali dalam hal kehadiran peserta didik dalam mengikuti Kegiatan Belajar Mengajar di madrasah. Pentingnya memberikan syarat kehadiran minimal $75 \%$ supaya peserta didik dapat menyerap materi pembelajaran secara sempurna sehingga meningkat prestasi belajarnya.

4) Pada aspek pencapaian program, pentingnya tinjuan ulang dalam teknis pembelajaran membaca al-Qur'an. Perlunya standarisasi pendidik dalam tahsin tilawah al-Qur'an, metode pembelajaran al-Qur'an serta penambahan jam mata pelajaran membaca alQur'an. Pembelajaran membaca al-Qur'an ini ditekankan pada sisi kaidah tajwid kepada peserta didik sehingga menghasilkan kualitas lulusan madrasah dengan standar ideal dalam membaca al-Qur'an, bukan sekedar lancar atau bebas dari buta huruf al-Qur'an. Kemudian dalam hal praktek ibadah tentunya tidak hanya sekedar pengetahuan kognitif belaka dalam hal fikih ibadah namun perlu ditekankan motivasi bagi peserta didik dalam sisi aplikasi pelaksanaan ibadah dalam kehidupan seharihari. Dari segi afeksi/perilaku/akhlakul karimah perlu menjadi perhatian bagi penyelenggaraan Madrasah Diniyah Takmiliyah sehingga hasil dari pendidikan membuahkan hasil berupa internalisasi nilai-nilai islami dalam kehidupan sehari-hari para peserta didik.

5) Penyelenggara pendidikan madrasah Diniyah Takmiliyah diminta cakap dalam berkolaborasi dengan elemen-elemen lain misalnya dengan Pemerintah Kota, Kementerian Agama, Majelis Ulama Indonesia, Forum Komunikasi Diniyah Takmiliyah (FKDT) setempat serta orang tua wali. Sinergi ini dibutuhkan untuk implementasi kebijakan, pengelolaan, pengawasan, pembelajaran, dan kegiatan evaluasi penyelenggaraan program pendidikan Diniyah Takmiliyah.

6) Terkait dengan masih ada peserta didik yang mengikuti penyelenggaraan Diniyah Takmiliyah dengan terpaksa, malas dan jarang hadir perlu dilakukan motivasi lebih intensif tentang manfaat dan tujuan program serta ketegasan untuk tidak mendapatkan ijazah/sertifikat Diniyah Takmiliyah dari satuan pendidikan madrasah.

d. Pendidik Madrasah Diniyah Takmiliyah

I) Kepada pendidik Madrasah Diniyah Takmiliyah hendaknya meningkatkan pemahaman tentang administrasi pembelajaran. Dengan demikian, mereka dapat mengetahui ke mana arah kurikulum Madrasah Diniyah Takmiliyah akan dibawa, sehingga dapat menghantarkan tujuan secara efektif dan efisien.

2) Kepada pendidik hendaknya terus mendukung program penyelenggaraan Madrasah Diniyah Takmiliyah dengan cara aktif menjadi pembina, 
fasilitator serta motivator peserta didik dalam mengembangkan potensi dirinya untuk berkembang menjadi manusia Indonesia yang unggul cerdas berwawasan namun tetap memiliki landasan nilai moral agama yang kuat.

3) Pendidik Diniyah Takmiliyah perlu mendorong dalam aktualisasi dan implementasi dari ilmu, wawasan serta kognisi dari pembelaran keagamaan. Tujuan pendidikan bukan saja mengarah pada bentuk kognisi/pengetahuan dan secara dogmatis saja, namun berlangsungnya persemaian afeksi, perilaku, amaliyah, akhlak, budi pekerti, jati diri pada diri peserta didik di berbagai tempat. Pendidikan Diniyah Takmiliyah sebaiknya mengarahkan dalam pengamalan dan perilaku riil dalam aktivitas kehidupan sehari-harinya dengan landasan norma agama tersebut. Perlunya pola pengajaran dan pendidikan diperlukan pembiasaan, keteladanan dan rekonstruksi pemikiran masyarakat (peserta didik) terkait dengan betapa berharganya nilai-nilai agama untuk diterapkan dalam kehidupan sosial. Oleh sebab itu, pendidik di program pendidikan diniyah takmiliyah harus berupaya seoptimal mungkin supaya menjadi role model atau uswatun hasanah dari peserta didiknya dalam berperilaku sesuai dengan penerapan ajaran agama yang diajarkannya

e. Kementerian Pendidikan dan Kebudayaan Republik Indonesia

I) Kebijakan pemerintah pusat tentang full day school perlu ditinjau ulang karena sangat berimbas dalam penyelenggaraan Madrasah Diniyah Takmiliyah di lapangan. Faktor ini tidak hanya di Kota Banjar namun di banyak daerah yang memiliki program penyelenggaraan Madrasah Diniyah Takmiliyah. Kalaupun diterapkan kebijakan tersebut, harus ada kebijakan pula bagi Madrasah Diniyah Takmiliyah supaya kegiatan belajar mengajar dapat dilaksanakan tanpa mengurangi esensi arah tujuan yang ingin dicapai oleh penyelenggaraan Madrasah Diniyah Takmiliyah. Bagaimanapun juga Madrasah Diniyah Takmiliyah menjadi bagian dari Sistem Pendidikan Nasional yang perannya sangat dibutuhkan oleh masyarakat guna memberikan tambahan serta melengkapi pendidikan keagamaan Islam bagi peserta didik.
2) Berdasarkan hasil evaluasi di atas, Kementerian Pendidikan dan Kebudayaan RI diharapkan menerbitkan kebijakan yang mewajibkan pendidikan keagamaan Islam bagi peserta didik yang beragama Islam terutama peserta didik pada sekolah negeri guna menambah dan melengkapi Pendidikan Agama Islam yang mereka dapatkan di sekolah formal. Dengan demikian dapat menyeimbangkan pengetahuan umum mereka di sekolah dengan internalisasi nilai-nilai agama sehingga terjadi perubahan karakter peserta didik menjadi lebih baik.

\section{Daftar Pustaka}

Anas, Sugiono. Pengantar Evaluasi Pendidikan. Jakarta: Rajagrafindo Persada, 2008.

Arikunto Suharsimi, Cepi Safruddin Abdul Jabar. Evaluasi Program Pendidikan; Pedoman Teoritis Praktis bagi Mahasiswa dan Praktisi Pendidikan. Jakarta: Bumi Aksara, 2014.

Azizi, Yahya. The Using of Model Input, Process and Product (CIPP) in Learning Program, 200I.

Direktorat Pendidikan Diniyah dan Pondok Pesantren Kementerian Agama Republik Indonesia. Buku Pedoman Penyelenggaraan Madrasah Diniyah Takmiliyah. Jakarta, 20I4.

Instruksi Kepala Daerah Kota Banjar Nomor 422/Ins. I32-Huk/05/2005 tentang Persyaratan Memasuki Sekolah Lanjutan Tingkat Pertama (SLTP) dan Sekolah Menengah Tingkat Atas (SLTA) di Kota Banjar Bagian Kedua.

Keputusan Direktur Jenderal Pendidikan Islam Kementerian Agama Nomor 2349 Tahun 2012 tentang Pedoman Pengembangan Kurikulum Madrasah Diniyah Takmiliyah Lampiran I.

Maksum, Madrasah. Sejarah dan Perkembangannya. Jakarta: Logos Wacana IImu, 1999. 
Supriyanto

Burhanuddin Tola

Peraturan Daerah Kota Banjar Nomor 18 Tahun 2013 tentang Penyelenggaraan Pendidikan Al-Qur'an dan Madrasah Diniyah Takmiliyah

Peraturan Menteri Agama Republik Indonesia Nomor 13 Tahun 2014 tentang Pendidikan Keagamaan Islam

Peraturan Pemerintah Republik Indonesia Nomor 55 Tahun 2007 tentang Pendidikan Agama dan Pendidikan Keagamaan

Sabaraguna S Boy. Analisa Data pada Penelitian Kualitatif. Jakarta: UI Press, 2000.

Sudjana Djuju. Evaluasi Program Pendidikan Luar Sekolah; untuk Pendidikan Nonformal dan Pengembangan Sumber Daya Manusia. Bandung: PT Remaja Rosdakarya, 2008.

Wirawan. Evaluasi, Teori, Model, Metodologi, Standar, Aplikasi dan Profesi Jakarta: PT Raja Grafindo Persada, 2016. 